\title{
Attending to political conflict in social work today and in the near future
}

\author{
Focus on European social work
}

\begin{abstract}
This paper is aimed at looking at how social workers in Europe tackle the inevitable political issues embedded in their work as intermediaries between political authorities (governments and local authorities) and social work clients affected by political conflict. The notion that social work can be a-political is rejected from the outset. The outcomes of armed political conflict for the populations involved, as well as for social workers who are citizens in these countries, and who remain in their country of origin, are briefly looked at. The migration wave of 2015-2017 and its aftermath is used as the key example with which to explore further the issue of clash between social work values and those of the majority of the European member states governments. Key changes taking place since 1980s in political ideologies of these states, including the issues of nationalism alongside neoliberalism and imposed changes in the welfare state which reveal going back to pre 2 nd World Warperception of poor, disabled, and destitute peopleare examined. The impact of thesechanges on attitudes towards refugees, asylum seekers and migrants are investigated. Some key examples of social workers attempting to change the worsening situation for their clients are given. The paper ends in considering the options for social workers wishing to follow the values of social work in their collective and individual practice.
\end{abstract}

Key words: migration, illiberal state, authoritarianism, welfare systems, refugees, asylum seekers.

Shulamit Ramon is professor of social inclusion and wellbeing at the University of Hertfordshire, in the social work section. Contact: s.ramon@herts.ac.uk.

\section{Spoprijemanje s političnim konfliktom v socialnem delu danes in v bližnji prihodnosti - Osredotočenost na evropsko socialno delo}

Članek prikaže, kako se socialni delavci in delavke spoprijemajo z neizogibnimi političnimi vprašanji, ki so sestavni del njihovega dela, ko delujejo kot posredniki med političnimi oblastmi (vladami in lokalnimi oblastmi) ter uporabniki socialnega dela, ki so žrtve političnih konfliktov. Avtorica že na začetku zavrne idejo, da bi bilo socialno delo lahko apolitično. Na kratko predstavi posledice oboroženih političnih konfliktov za vpleteno prebivalstvo pa tudi za socialne delavke in delavce, ki so državljanke in državljani teh držav in ki ostajajo v izvorni državi. Migracijski val v letih 2015-2017 in njegove posledice uporabi kot ključni primer, s katerim je mogoče podrobneje raziskati vprašanje spopada med vrednotami socialnega dela in vrednotami večine vlad članic Evropske unije. Avtorica razišče ključne spremembe, kise dogajajo od osemdesetih let 20. stoletja v političnih ideologijah teh držav, med drugim vprašanje nacionalizma v kombinaciji z neoliberalizmom in vsiljenimi spremembami socialne države, ki razkrivajo percepcijo revnih, oviranih in obubožanih ljudi, ki sega še v čas pred drugo svetovno vojno. Avtorica preuči vpliv teh sprememb na odnos do beguncev, prosilcev za azil in migrantov. Poda nekaj ključnih primerov socialnih delavk, ki poskušajo izboljšati situacijo svojih uporabnikov. Članek sklene z možnostmi, ki jih imajo na voljo socialni delavci in delavke, $k i$ želijo upoštevati vrednote socialnega dela v svoji organizaciji in svojem osebnem življenju.

Ključne besede: migracije, neliberalna država, avtoritarianizem, socialni sistemi, begunci, prosilci za azil.

Shulamit Ramon je profesorica za socialno vključenost in blaginjo na Univerzi v Hertfordshiru v Združenem Kraljestvu, na oddelku za socialno delo. Kontakt: s.ramon@herts.ac.uk.

\section{Introduction}

This paper will focus on the responses of European countries to the migration wave of 2015-2017, and the related underlying changes in political ideology and welfare policies of the near past. 
Mentioning political issues in social work has been traditionally unfashionable in social work and other helping professions as such issues were/are perceived as too ideological, in contrast to the assumed non-political and non-ideological stance of being an "objective" professional. By now we are aware that it is impossible to be de-voided of beliefs and biases by virtue of being a human being within a specific social context, and that every professional discipline comes with a set of values which expresses its ideological beliefs (Harding, 1995). The long process of socialisation into a specific helping profession serves also to enforce their acceptance of these values, which is reinforced later on through their membership in a community of professionals.

The discourse on human rights and social work values has replaced that of ideology to a large extent, though most social workers avoid expressing overt political views even when their values are in conflict with the prevailing views of their employer, the government and majority political party of the day. It is left to national and international professional association to express politely the political stance of the profession in most formal democracies. However, at crisis times, such as the migration wave to Europe of 2015-2017 and its aftermath, the impact of political conflict this wave has on social work is such that ignoring it becomes a more demanding task.

During armed political conflict, of which we have internationally an exponential increase since the beginning of the $21^{\text {st }}$ century, it becomes more difficult for social workers living in such a context to remain uninvolved politically both individually and collectively, and social workers' lives may be threatened (see e.g. Almeida, 2008; Lindsay, 2008; Sánchez, 2008). However, this position continues to be an explicit part of the requirements of social workers.

\section{Testing adherence to social work values}

In armed political conflict social workers are at the receiving end of such a conflict by virtue of being citizens of a society undergoing armed conflict, as well as its impact on their professional activities, including witnessing the suffering of their victim clients (Baum and Ramon, 2010). A good example of taking a clear political stance, yet remaining within the Human Rights discourse, is the creation of Social Work Without Borders (SWWB) associations in more than one European country in response to governments' modes of handling the unaccompanied children who were based in Calais (Wroe, Larkin and Maglajlić, 2019).

Some of the discomfort to take a stand in political conflicts relates to the co-existence of positive and negative aspects of the political activities taken by national organisations. These include national armies' activities, which include highly unethical responses to the populations perceived as being the enemy. For example, I have begun writing this paper on $27^{\text {th }}$ June 2020, which happens to be the Armed Forces Day in the UK. I just got a request to sign a petition in support of the UK armed forces. Yet while I recognise that there is a need for an army to defend a country against an attack by its enemies, as highlighted during the Second World War, I am also aware of a number of cases from more recent 
armed conflicts, such as in Afghanistan (2001) and Iraq (2003), when the same army committed atrocities against civilians which the Ministry of Defence did its best to hide, even when such cases were brought to court (Williams, 2011).

Yet at times there are positive responses of governments and social welfare organisations which are important to recognise and to take account of. The generosity of the UK government in 1938 of enabling 10,000 mainly Jewish children from Central Europe to come to the UK just before the $2^{\text {nd }}$ World War begun, named the Kindertransport (Guske, 2009), followed by the generosity of the British public to offer hospitality to these children free of charge remains an outstanding example, which has not been repeated since.

\section{The 2015-2017 migration wave}

Table 1: Arrivals to Europe and first applications for asylum.

\begin{tabular}{|c|c|c|}
\hline Years & All arrivals from non-EU countries & First applications for asylums \\
\hline 2014 & 594,180 & 530,560 \\
\hline 2015 & $1,282,690$ & $1,216,860$ \\
\hline 2016 & $1,221,185$ & $1,166,815$ \\
\hline 2017 & 677,470 & 620,265 \\
\hline 2018 & 608,335 & 548,955 \\
\hline 2019 & 676,250 & 612,685 \\
\hline
\end{tabular}

Source: Eurostat, 2020.

The table 1 highlights the move of the wave over the six years from 2014 to 2019 and the fact that most of the migrants opted to apply for asylum seeking. The table also illustrates the peak of this wave in 2015, the reduction in the numbers after 2015, and the increase in 2019, indicating that the migration story is not moving only in one direction.

A total of 79.5 million people were displaced by the end of 2019 , including 33 million refugees living away from their country of origin, while 50.8 million were internally displaced in their own country, and hence not in Europe (Norwegian Refugee Council, 2020). In 2016 362,000 refugees/asylum seekers came by sea to Europe. Of these, 181,400 came to Italy via Libya, and 173,450 to Greece via Turkey. Both Greece and Italy were already in an insecure economic state since the economic crisis of 2008.

By September 2019, there were 470,000 first time asylum applications to European countries. Of these, 282,100 were provided by six European countries: Germany $(111,000)$, France $(87,100)$, Spain $(80,000)$, Greece $(47,000)$, UK $(32,000)$ and Italy $(25,000)$ (UNHCR, 2020). This means that the majority of EU countries (22) offered much less than these six countries.

Most of the newcomers came from Syria, Afghanistan, Somalia and South Sudan, with smaller numbers from other African countries, including North Africa (Europe Stability Initiative, 2017). Those coming from the Middle East and Asia were fleeing from armed political conflicts, while those who came 
from Africa were labelled as economic migrants, even though a number of their countries were in the midst of an armed conflict or its aftermath too. According to the UN Charter those fleeing an armed political conflict are entitled to be given the status of refugees, while those fleeing hunger are not (UN Convention and Protocol relating to the Status of Refugees, 2020). This division does not take into account that the impact of an armed political conflict continues long after the formal armed component has ceased.

Most of the arrivals came illegally, while they paid smugglers substantive sums provided by their families. Most of them were young men, with a much smaller number of young women, and some families. This distribution highlights that sending the young men was a collective act of an attempt to secure a better future for the next generation as well as the hope that the young men will do their best to support their families later on, either financially and/or by bringing them too to a European country. All of them came after experiencing hardship, be it economic, political, psychological or physical in nature. Yet according to international treaties co-ordinated by the United Nations each of these categories have different rights, entitlements, and status in the host country.

\section{Internally displaced people}

However, this categorisation omits the most prevalent group of people who have become displaced in their own country due to political conflict, whom we call internally displaced people (IDP).

As mentioned above, according to the Norwegian Refugee Council (2020) we had by the end of 201950,8 million IDPs, none of whom was/is entitled to any international status. These are people who had to flee their homes usually due to political conflict in which they were on the losing side, and hence seen by their own government as part of the enemy camp. They often left home without their documents, attempting to reach relatives living in other parts of the same country. Their move was often resented by the inhabitants of the areas they escaped to, due not only to being perceived to be part of the enemy population, but also due to economic competition and lack of housing.

Social work services, and even elementary education schooling, are all too often disrupted in these areas due to armed political conflict, and at times due to natural disasters (Herath and Lešnik, 2008). The few remaining overworked social workers deal mainly with financial issues and rarely provide emotional support. These populations have experienced a great number of traumas, such as witnessing atrocities, loss of family members, being injured and becoming physically disabled, loss of home, loss of belongings, loss of employment, loss of social status, experiencing segregation and discrimination by the majority population and government. Where possible, either women or men would move to work in another country, to secure a better life for the whole family, at the cost of family separation and often leading a lonely life working in a low status occupation, such as being a servant or a manual labourer. The likelihood of returning back to their previous home depends on politically agreed solutions reached by politicians in which the IDP population is unlikely to be involved. 


\section{Back to Europe of the $21^{\text {st }}$ century}

Europe has witnessed a large scale armed political conflict towards the end of the $20^{\text {th }}$ century, when Yugoslavia came to an end as a national and political entity in the 1990s. This affected differentially the populations in the different states which were members of the Yugoslav federation, depending in part on how long the armed conflict was, its intensity, the level of physical, material and emotional losses experienced by local people. In some parts of ex-Yugoslavia, such as in Bosnia and Herzegovina, the war was bitter and impacted the local population harsher in terms of the number of people killed, injured, imprisoned, tortured, massacred, houses burnt, bridges destroyed, livelihoods disappearing (Zaviršek, 2008; Maglajlić Holicek and Rašidagić, 2008). A substantial number of people became refugees either in another part of Yugoslavia, or moved to other European countries and beyond (e.g. Germany, UK, Australia, Canada, USA). This conflict required the involvement of the United Nations to reach ceasefires and then a peace agreement, and a UN force to stay in the territory for a couple of years. It also took place in parallel to the change in regimes in Central Europe from Socialist/Communist and from totalitarian regimes (e.g. East Germany, Poland), to more parliamentary democratic ones.

Although all of the above took place in the relatively recent past, most of these central European countries have denied refugee status and legal asylum-seeking status to many of those who came in the 2015-2017 migration wave, unlike countries such as Germany and Sweden.

The EU, which includes by now two of the ex-Yugoslavian states, with others attempting to join, failed to reach an agreement concerning the quotas of asylum seekers each member state would take, just lumping Greece and Italy with a much higher number of refugees than elsewhere in Europe, and encouraging the border police of each country to remove by force those attempting to come through, even if they aimed to move to yet another European country. Some border police forces excel in the brutal way they treat the refugees.

The EU central authorities continue to pay Turkey, Greece and Italy for the cost of keeping the refugees, while the UN contributes to the cost of Greece and Italy as well as for the upkeep of the $3^{\text {rd }}$ generation of Palestinian refugees whose grandparents left what is currently the state of Israel in 1948 and in 1967 , as they continue to live in camps in the Gaza strip, Jordan and Lebanon (Lindsay, 2008).

We need to understand what has motivated the $22 \mathrm{EU}$ states not to accept refugees, as well as to limit considerably their reunification with family members already settled in some EU countries, such as the UK.

\section{Illiberal authoritarian European states}

Several of the 22 countries have moved formally to much more authoritarian regimes since the beginning of the $21^{\text {st }}$ century, notably Hungary and Poland (An, Chubarova, Deacon and Stubbs, 2019). These countries are openly nationalistic, encouraging populism, opposing liberal values, regimes and organisations, and discriminating against minority populations within their own 
jurisdiction. This tendency includes opposition to gender studies, feminism, minority sexual orientation, giving more authority to the prime minister or president, and less power and rights to ordinary citizens or the judiciary. Welfare rights to poor and disabled people are curtailed and neoliberalism is championed as the only right ideology to adhere to (Landvai-Bainton, 2019).

They are formally members of the EU, even though they do not adhere to some key values of this organisation. As already mentioned, most of these countries were part of the socialist, pro Soviet, block until 1990 (see also Zaviršek and Rajgelj, 2018). Perhaps this is due to the sense of economic and political insecurity that came with the move to formal parliamentary democracy not so long ago.

The UK move to leave the EU reflects nationalistic tendencies too, and its strong adherence to neoliberalism. It has followed a neoliberal regime since 1982, which included lack of belief in the existence of collectives, did away with community social work, reduced considerably the power of the trade unions, and re-established a pre-welfare state regime based on the assumption that welfare recipients are undeserving people who are responsible for their misfortune, and treating non-white legal migrants with suspicion. While Scott-Samuel et al. (2014) analysed the impact on health and well-being, Kus (2007) provides a methodical comparison of how Britain and France treated the welfare state when they adopted neoliberalism, demonstrating a very different response in each country in the 1980s.

Furthermore, in the $21^{\text {st }}$ century, the UK home office minister Teresa May, who became Prime Minister between 2016 to 2019, called for a number of steps to limit any type of migration drastically, which included a call for a hostile environment towards migrants by its civil service. Furthermore, the 2016 historical decision endorsed by the House of Commons and the House of Lords allowed unaccompanied children stuck in Continental Europe who had relatives in the UK to be reunified with their families (the Dubs amendment - the mover of this amendment, Lord Dubs, came to the UK as child in the Kindertransport; see Dubs, 2019). To date (2020) only 350 such children have been allowed to enter the UK out of an estimated number of 3000 , with the Home Office claiming that it does take a long time to check if the claim made by a child to come to the UK is valid. Mrs. May also presided over the decision to expel from the UK 83 people who came from the Caribbean islands as children between 1948 to 1973 whose documents were shredded by the Home Office and who have not kept copies of their UK citizenship documents after living in the UK for most of their lives; known as the Windrush scandal. Windrush was the name of the first ship that brought these people to the UK in 1948, at the request of the British government for them to come due to the shortage of workers in the immediate post $2^{\text {nd }}$ World War (UK Parliamentary Human Rights Joint Committee, 2018; Joint Council for the Welfare of Immigrants, 2018). Many of these people spent months in UK Immigration Detention Centres as their families were attempting to stop their expulsion back to the Caribbean island from which they came, and which they did not visit for decades. This scandal ended by the resignation of the Home Office Minister, Mrs. Amber Rudd, who inherited this case from 
Teresa May, and awarding compensation for suffering and undue detention to the victims of this scandal. The requests for compensation are only slowly being responded to since 2018 .

The fact that the leaders of the illiberal authoritarian democracies have been elected democratically is often perceived to be reflecting the voters' fear of migrants. Such a fear is usually due to felt economic threat, namely that the migrants will take over the jobs of the natives, in part because of the migrants' readiness to work in any job and in any working conditions, and in part due to fear that their cultural difference - including religion - will diminish the accepted values of the host society (see the report by Berry, Garcia-Blanco and Moore, 2015, on the media coverage of the pre-2015 migration, and the article by Ebrel et al., 2018, on the migration wave of 2015-2017). This fear has increased since the 9/11 attack on the World Trade Centre in New York, followed by similar terrorist attacks in Europe, and it refers to fear of Islam, as well as black and brown skinned people.

It seems that the general public has forgotten that all European societies have had considerable internal and external migration waves since the end of the Second World War, as well as that in a number of cases the migrants were asked to come by the government of the host society (e.g. as mentioned above, the UK government invited people from the Caribbean island and the Indian sub-continent to come to work and live in the UK in the early 1960s); the EU gave the right to reside and work in another EU country to all citizens of the $\mathrm{EU}$, and in countries where this migration was left uncontrolled some native citizens felt that the East European migrants were taking their jobs. In reality, the majority of the jobs filled by the EU migrants were either jobs that native citizens did not wish to opt for (e.g. fruit pickers in season), or where there was labour shortage (e.g. doctors from other EU countries). Yet although there were always nationalistic and Fascist leaders inciting hatred of migrants in most European countries, the majority of the native population did not follow these leaders in the post Second World War period.

However, we have evidence of the general public moving to the political Right in countries scared of the impact of high numbers of asylum seekers on their economic stability. This is reflected in more people voting for right wing political parties in Greece and Italy - countries that have the highest number of refugees - as well as in countries with much smaller such numbers (Hungary, Poland, UK). This may be explained by the impact of the 2007-2008 economic crisis and the fear of terrorist attacks, even though the number of refugees/asylum seekers involved in such attacks is small.

A minority of social workers in each European country work consistently with refugees, asylum seekers and migrants. They follow the policies, laws and regulations of their country. The degree of their awareness of the background of their clients is unknown, and the theme of working with this population receives varied attention on their educational curriculum. Most of their work focuses on unaccompanied children (Clayton, Gupta and Willis, 2019), an area in which most European countries take the responsibility to ensure the basic rights of children to a decent life, which is in line with the much greater focus 
on working with children in need of protection than working with adults of working age, or older people in each of these countries. The budget allocation follows this focus too. The work with the children focuses on their wellbeing and integration to the new society, and with some of them on family reunification. It would seem that little attention is given to the child's background and the experiences the child may have had at home before leaving, or on the journey to the host country, and in the host country. This focus does imply relative neglect of adults of working age and older people by social services.

Visiting statutory and voluntary services for this client groups in Greece, Italy, Slovenia and UK in 2019 (Ramon and Cox, 2020 ) in a project sponsored by BASW IDF (International Development Fund), I have come across very dedicated staff of both psychologists and social workers to whom children have become attached, who also ensured that the refugee children were connected to local children, teachers, and families. The work on family reunification is demanding in time as well as due to the need to judge from afar the suitability of the family member who offers to have the child. Some children do not adjust easily to the host country's environment, especially when they enter adolescence.

It is also in the context of working with teenagers that the thorny issue of age assessment comes into focus, as the legal systems of most countries requires to ensure that those who pretend to be below 18 but who are above this age marker will be identified by social workers and other professionals (Immigration Law Practitioners' Association, 2007). The legal system assumes culpability of the adolescent child, and is uninterested in the motive behind claiming to be younger than one is. Yet the social worker can, and does, understand the motive, as well as the all too often repulsive nature of the age assessment process. Thus a potential conflict between different social work values, between the legal system and the social work system comes to the fore, and within the legal system itself.

Clayton, Gupta and Willis (2019), who have been active in working with unaccompanied children in Calais, have written about the lack of co-ordination between the French and the English governments concerning the processing of this group on French soil, prior to entering UK, even though they have formally agreed on what needs to be done and by whom. While the children were stuck in Calais for a long time with nothing better to do, it would have been both useful and humane to undertake the asylum processing of the children to completion, so that when they entered the UK they could go either directly to their relatives or to the alternative housing arrangement prepared in advance, thus reducing the tension, anxiety and insecurity of the final phase of their physical migration process.

However, the UK government has not responded to the many attempts by the French government to sort this matter out in advance. Consequently, when the number of asylum seekers in Calais has reached its boiling point, the French had to evacuate everyone by force, including the unaccompanied children, thus adding to the long list of traumas these children have already experienced. A large number of children have disappeared at that stage - no 
one knows if they were trafficked, went back to Calais after a few weeks to live in tents, went to another part of France, or to any of the bordering countries with France (Belgium, Germany, Spain, and Switzerland). The UK volunteers in Calais, a number of whom were social workers doing so in their non-work time, spent most of their time sorting out donated food and cloths. Some of them, such as the art therapists, arranged non-verbal activities mainly with the young adults refugees, enabling them to express their frustrations and hopes in clay or drawings. A number of the young adults in Calais spend their nights attempting to enter illegally the UK, endangering themselves by jumping into lorries, while learning English during the day. In early 2019, a group of 30+ young Vietnamese died at the back of such a lorry coming via Ostend, having each paid a substantial sum to the smugglers who promised to take them to the UK.

The second substantial group of asylum seekers are the post 18 young adults (Allsopp and Chase, 2017; Williams, 2019). This is the most visible group in any of the refugee camps, consisting primarily of young men, walking and talking on their mobiles, with little else to do and too little funding to be able to even take a bus to the city centre, while waiting for months on end to secure the international refugee status. If lucky, they live in a dormitory of a hostel for asylum seekers; if unlucky, they live in a tent or in the open air where it is too hot in the summer and too cold in the winter. Most of the post 18 in the host countries came over as unaccompanied children, and were transferred from the children service to the adult services when they reached their $18^{\text {th }}$ birthday. The support they are entitled to is lower than their entitlement as unaccompanied children, based on the assumption that becoming young adults they should be studying or working in the host country. However, if their right to stay in the country has not been clarified, or they wish to move to another European country, they are not allowed to work and can stay on a limbo for a long time. Although some have secured the right to citizenship in the host country, they all too often do not have the necessary funding to pay for a passport (e.g. the cost of a UK passport is by now $£ 2,000$, a huge sum for an unemployed young refugee who lives on a small social security benefit).

Thus, in many cases the considerable work invested in an unaccompanied child who has become 18 is wasted, alongside hopes and ambitions the young person may have had. Some young people succeed against the odds to continue their studies and to gain a job. These lucky young men are likely to have been helped usually by a voluntary organisation, and at times by a statutory one if they have an identified need and eligibility, such as a minor disability.

Williams (2019) discusses the implications of the "durable solutions" outlined by the UNHCR (2003) for the post 18 asylum seekers, namely returning to their home country, remaining in the host country with the status of international refugee, and resettlement in as yet a third country. Given the level of violence in the countries from which most of the young adults came as unaccompanied children, such a return is undesirable, and resettlement in a third country they do not know is equally undesirable unless it is part of a family reunification plan. Staying in the host country remains therefore the 
preferred solution in most cases, although its desirability fades if the young person's request for an international refugee status has been rejected, often more than once, by the host country. The message of being unwanted is thus delivered loud and clear by social workers to these young adults who find themselves in a limbo concerning their present and future lives. They are officially supported by social workers in the host country, who may be as despairing as the young adults are with repeated rejections and the barriers these are creating for a better future for the clients who have been separated from their families for a long time.

The instability of the lives of the young adults has been demonstrated recently in the stabbing incident in a central Glasgow hotel on 26/6/2020, which hosted 350 asylum seekers for the duration of the Covid-19 lockdown, to ensure that they are not exposed to the pandemic due to the poor living conditions they usually have. The report by United Nations House (2020) in Scotland explicitly mentions the high level of tension among the residents, due to their fear that they will have soon to leave the hotel and move back to the sub-standard accommodation they had before. Apart from one policeman, all other victims were asylum seekers, as was the attacker. The report mentions that the asylum seekers live on a daily allowance of $£ 5.39$, and that they were in fact detained in the hotel, unable to go out. The sum of $£ 5.39$ is below the UK minimum pay per hour, yet the asylum seekers are supposed to live on less than that per whole day.

Thus, the treatment of this group in a number of European countries highlights the negative attitudes of the host countries' governments and the lack of concern of the fate of this group by the general public. The exceptions to the above is demonstrated by social workers and lawyers of statutory services and in particular by the voluntary organisations operating on a shoestring on behalf of this neglected sub-population.

In addition, social workers in the UK established in 2016 a voluntary organisation titled Social Workers Without Borders (SWWB) ${ }^{1}$, which offered pro-bono age assessment wherever needed, and has since become an international organisation, with branches in many other countries (e.g. Australia, Canada, Jordan, India, Italy, New Zealand, USA) (see Wroe, Larkin and Maglajlić, 2019). They began by offering to carry out the "Needs and Best Interest Assessment" to unaccompanied children stranded in Calais at the time, in support of their legal application to enter the UK. They continued to support those children in France and upon arrival to the UK, all in their non-work, private, time and without pay. By the summer of 2017 they branched out to support parents and children who face removal from the UK, due to having insecure immigration status (King, 2019).

While SWWB deserve to be commended for the courage and commitment of its members, doing so in individual voluntary capacity is unlikely to be sufficient to lead to the policy and practice changes that their activities indicate to be necessary. UK social workers did manage to successfully oppose their

1 See their website: https://www.socialworkerswithoutborders.org/swwb-international. 
involvement in doing X-rays as part of the age assessment process, but all of what this has meant is that another professional group is carrying out this part of the process, despite the persisting doubts as to the ethical value and accuracy of using X-rays to identify the exact age of a young asylum seeker.

It would therefore seem that given the worsening of upholding social work values in Europe, both in the context of welfare policies practice, as well as concerning the migration wave of 2015-2017 and its aftermath, European social workers need to attempt to have an impact on policy making as well as on the implementation of policies concerning political conflicts which affect them either directly or indirectly. This is primarily a role for the national organisations of each European state, and the European Federation of Social Workers (IFSW), as well as the International Association of Schools of Social Work (IASSW).

Engaging fieldwork social workers, service users, educators and researchers is the first step to be taken. In parallel, each social worker needs to learn how to challenge the authorities effectively when a proposed solution is considered by them and by the asylum seeker to be unsuitable, thus ensuring that their values do not remain at the lip service level.

Williams and Briksman (2015) propose that social work can be revived through moral outrage. It seems to me that while there is a place for moral outrage as a motivator, and as an expression of righteous anger, it needs to be followed by a pathway of knowing what social workers wish to achieve at the micro level of doing their best with and for their clients, meso level with their service directors, and macro level through their national and international association.

Both UK and continental European social workers recognise the inherent conflict in the position of local authorities being responsible for both the assessment and the appeal process against assessment outcomes (Bianchini, 2011; Separated Children in Europe Programme, 2012) and some practitioners have managed to put in place a system that supports unaccompanied children who wish to challenge these outcomes (Ortiz, 2019, p. 247). These partial successes illuminate what can be achieved, though the road to changing the system seems to be a very demanding one.

\section{Implications for the near future}

This article is being written while we are all in the midst of Covid-19 pandemic, with some European countries doing better than others, as well as ups and downs in the struggle to stop the pandemic.

There is little doubt that the pandemic hits more severally poor and unwell people, who are the bulk of social work clients. Asylum seekers are a group badly affected by the Covid-19, even though most European countries do not even publish the statistics of Covid-19 infection among this population.

This is made much worse when the asylum seeker has been deemed as having no recourse to further public funding, given that s/he - or a whole family - have nothing else to live on, cannot move to another country, and in a number of cases is kept in quarantine conditions. 
In addition, in most European countries the face-to-face contact with clients has been reduced considerably as part of ensuring the necessary social distance for keeping both clients and workers safe. Hence, these are very demanding times for social workers across Europe.

Maintaining the best possible standards of contact with clients has become a necessary and urgent objective. Social workers have to learn how to use effectively telephone conversations and online communications if available. These contacts have become more precious for both clients and social workers. Some social work departments, and some national social work associations, have developed special Covid-19 resources which focus on the use of the phone and online communication.

Doing their best to ensure that this group of clients does indeed receive what a particular country, or local authority, states it will offer member of the group, be it in cash, housing, food, access to health and educational services, is the second objective.

Preventing abuse of human rights is the third objective, as meeting obligations towards asylum seekers is not at the top of the current agenda of government departments, municipal authorities and the police. This objective requires social workers to be aware of abuse of human rights and to then intervene to stop it. They may need the support of their own department and national associations in doing so.

Fourthly, attracting public attention to the fate of this large group in the context of the Covid-19 is an objective that social workers are not used to, as it goes beyond the remit of contacts with clients and relevant service providers. However, given that mass media is at best divided in its positive and negative portrayal of asylum seekers in most countries, yet it continues to be a considerable influencer of public opinion, which in turn impacts also on politicians, it is an objective that has to be taken on. This is where the role of local and national associations is critical in engaging both different layers of mass media and in engaging individual social workers in what is a voluntary activity.

The example outlined above of Social Work Without Borders highlights what is possible due to voluntary activity of social workers. Working with journalists is essential in achieving this objective, as well as working with voluntary associations, such as existing refugees/migrants organisations.

Above all, the continuation of offering an empathic, caring, and effective response to individual and families of asylum seekers is the overriding objective for social workers in this type of demanding and rewarding social work.

\section{Sources}

Allsopp, J., \& Chase, E. (2017). Best interests, durable solutions and belonging: policy discourse shaping the futures of unaccompanied migrant and refugee minors coming of age in Europe. Journal of Ethnic and Migration Studies. Doi:10.1080/1369183X.2017.140265.

Almeida, S. S. de (2008). The participation of social workers in a human rights programme in Brazil: ethical-political challenges. In S. Ramon (ed), Social work in the context of political conflict. Birmingham: Venture Press (13-34). 
An, S., Chubarova, T., Deacon, B., \& Stubbs, P. (eds) (2019). Social policy, poverty and inequality in Central and Eastern Europe and the Former Soviet Union: Agency and Institutions in Flux. Stuttgart: Ibidem Verlag.

Baum, N., \& Ramon, S. (2010). Professional growth in turbulent times. Journal of Social Work, $13,163-182$.

Berry, M., Garcia-Blanco, I., \& Moore, K. (eds) (2015). Press coverage of the refugee and migrant crisis in the EU: a content analysis of five European countries. Report submitted to UNHCR. Accessed on 21 August 2020 from https://www.unhcr.org/56bb369c9.pdf

Bianchini, K. (2011). Unaccompanied asylum-seeker children: flawed process and protection gaps in the UK. Forced Migration Review, 37, 52-53.

Clayton, S., Gupta, A., \& Willis, K. (eds) (2019). Introduction. Unaccompanied young migrants: identity, care and justice. Bristol: Policy Press (1-14).

Dubs, A. (2019). Forward: House of Lords. In S. Clayton, A. Gupta, \& K. Willis (eds), Introduction. Unaccompanied young migrants: identity, care and justice. Bristol: Policy Press (xv-xvii).

Ebrel, J.-M., Meltzer, C. E., Heidenreich, T., Herrero, B., Theorin, N., Lind, F., Berganza, R., Boomgaarden, H. G., Schemer, \& Strömbäck, J. (2018). The European media discourse on immigration and its effects: a literature review. Annals of the International Communication Association, 42(3), 207-233. Doi: 10.10801/23808985.2018.1497452

European Stability Initiative (2017). The refugee crisis through statistics. Accessed on 21 Aug 2020 from https://www.esiweb.org/pdf/ESI\%20-\%20The\%20refugee\%20crisis\%20 through\%20statistics\%20-\%2030\%20Jan\%202017.pdf

Eurostat (2020). Accessed on 20 August 2020 from https://ec.europa.eu/eurostat/statistics-explained/index.php/Asylum_statistics

Guske, I. (2009). Trauma and attachment in the Kindertransport context: German-Jewish child refugees accounts of displacement and acculturation in Britain. Newcastle: Cambridge Scholars.

Harding, S. (1995). "Strong objectivity": a response to the new objectivity question. Syntese, 104, 331-346.

Herath, S., \& Lešnik, B. (2008). Internally displaced persons: implications for the development of social work in Sri Lanka. In S. Ramon (ed), Social work in the context of political conflict. Birmingham: Venture Press (77-97).

Immigration Law Practitioners' Association (2007). When is a child not a child? Asylum, age, disputes and the process of age assessment. Accessed on 21 August 2020 from https:// ilpa.org.uk/wp-content/uploads/resources/13266/ILPA-Age-Dispute-Report.pdf

Joint Council for the Welfare of Immigrants (2018). Dossier of failure - Windrush and the hostile environment. London: Joint Council for the Welfare of Immigrants, $23^{\text {rd }}$ April 2018. Accessed on 21 August 2020 from https: https://www.jcwi.org.uk/windrush-scandal-explained

King, L. (2019). Social Work Without Borders. In L. Wroe, R. Larkin, \& R. A. Maglajlić (eds), Social work with refugees, asylum seekers and migrants. London: Jessica Kingsley Publishers (27-38).

Kus, B. (2007). Neoliberalism, institutional change and the welfare state: the case of Britain and France. International Journal of Comparative Sociology, 47(6), 488-525.

Lendvai-Bainton, N. (2019). Diversified convergence: uneven welfare trajectories in Central and Eastern Europe. In S. An, T. Chubarova, B. Deacon, \& P. Stubbs (eds), Social policy, poverty and inequality in Central and Eastern Europe and the Former Soviet Union: agency and institutions in flux. Stuttgart: Ibidem Verlag (263-282).

Lindsay, J. (2008). Dilemmas, opportunities, obstacles and achievements in training Palestinian social care workers and social workers. In S. Ramon (ed), Social work in the context of political conflict. Birmingham: Venture Press (217-244).

Maglajlić Holicek, R. A., \& Rašidagić, E. K. (2008). The role of NGOs in societies facing war: experiences from Bosnia and Herzegovina. In S. Ramon (ed), Social work in the context of political conflict. Birmingham: Venture Press (123-146). 
Norwegian Refugee Council (2020). GRID 2020: global report on internal displacement summary. Geneva: Internal Displacement Monitoring Centre.

Ortiz, E. (2019). Age assessment of unaccompanied minors. In L. Wroe, R. Larkin, \& R. A. Maglajlić (eds), Social work with refugees, asylum seekers and migrants. London: Jessica Kingsley Publishers (239-250).

Ramon, S., \& Cox, J. (2020). Promoting migrants and refugees social work: a comparative perspective. Birmingham: BASW International Development Fund (a copy can be obtained from s.ramon@herts.ac.uk).

Sánchez, D. (2008). Social work and professional training in post-dictatorship Chile. In S. Ramon (ed), Social work in the context of political conflict. Birmingham: Venture Press (271-292).

Scott-Samuel, A., Bambra, C., Collins, C., Hunter, D. J., McCartney, G., \& Smith, K. (2014). The impact of thatcherism on health and wellbeing in Britain. International Journal of Health Services, 44, 53-71.

Separated Children in Europe Programme (2012). Separated Asylum Seeking Children in Europe. Vienna: FRA European Agency for Children Rights.

UK Parliamentary Human Rights Joint Committee (2018). Windrush generation detention. London: HMSO 29/6/2018.

UN Convention and Protocol relating to the status of Refugees (2020). Accessed on 18 July 2002 from https://www.unhcr.org.uk/what-is-a-refugee.html

UNHCR (2003). Framework for durable solutions for refugees and persons of concern, 16 September, EC/53/SC/INF.3

UNHCR (2020). Figures at a glance. Accessed on 20 August 2020 from https://www.unhcr.org/ United Nations House (2020). United Nations report on the Glasgow Incident. Accessed on 4 July 2020 from https://www.unhscotland.org.uk/post/glasgow-incident-26-june-2020

Williams, A. T. (2011). A very British killing: the death of Baha Mousa. London: Vintage Books.

Williams, L. (2019). "Durable Solutions" when turning 18. In S. Clayton, A. Gupta, \& K. Willis (eds), Introduction. Unaccompanied young migrants: identity, care and justice. Bristol: Policy Press (187-210).

Williams, C., \& Briksman, L. (2015). Reviving social work through moral outrage. Critical and Radical Social Work, 3, 3-17.

Wroe, L., Larkin, R., \& Maglajlić, R. A. (eds) (2019). Social work with refugees, asylum seekers and migrants. London: Jessica Kingsley Publishers.

Zaviršek, D (2008). Social work as memory work in times of political conflict. In S. Ramon (ed), Social work in the context of political conflict. Birmingham: Venture Press (147-168).

Zaviršek, D., \& Rajgelj, B. (2018). Anti-refugee sentiment without refugees: human rights violations and social work in post-socialist countries of Southeastern Europe in their social contexts. Journal of Human Rights and Social Work, 4(1), 5-16. Accessed on 21 August 2020 from http://link.springer.com/article/10.1007/s41134-018-0083-2 